ORNL/LTR-2014/320

\title{
DOE-NE Letter Report: Key Parameters for Operator Diagnosis of BWR Plant Condition during a Severe Accident
}

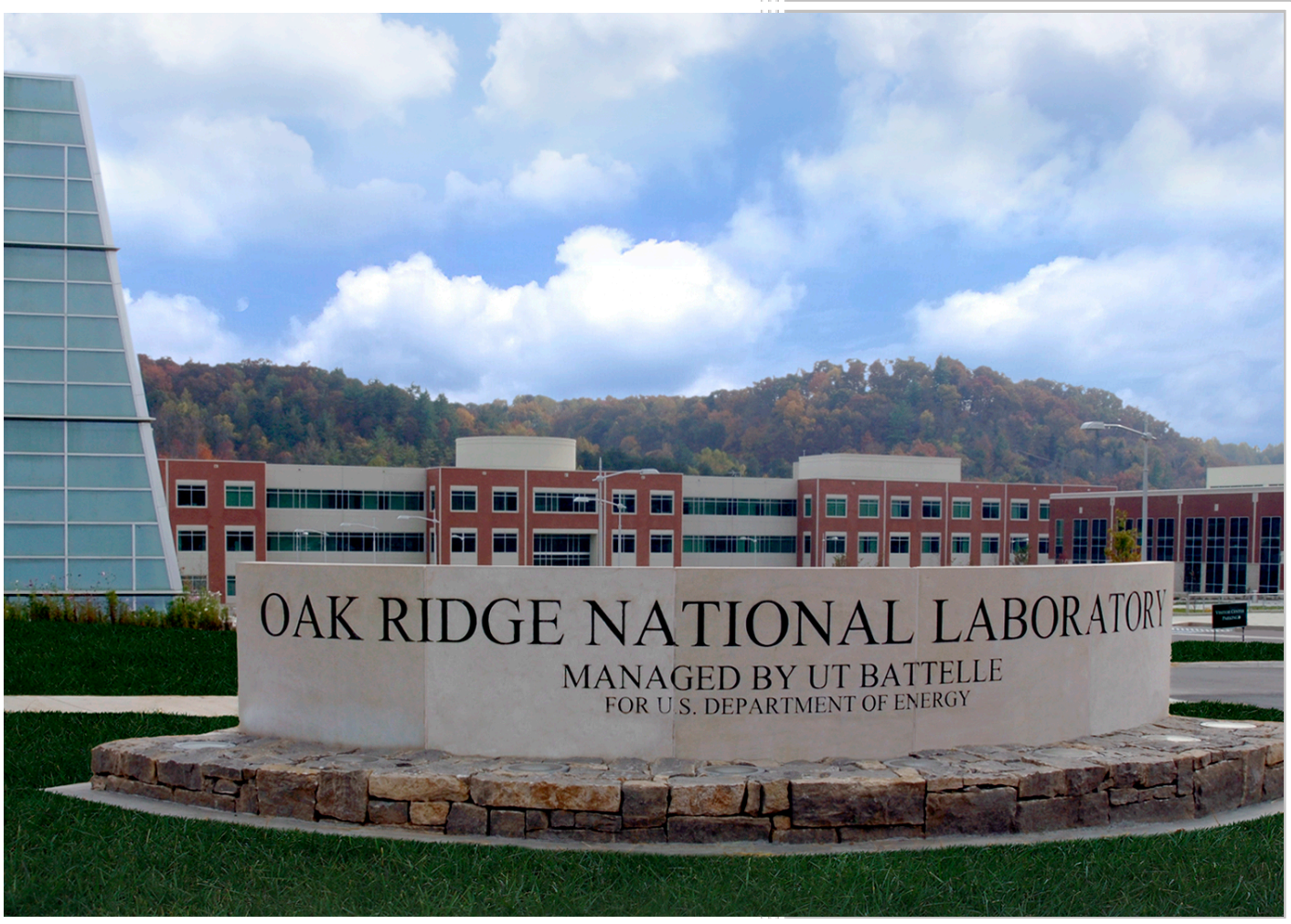

Approved for public release; distribution is unlimited.

Dwight Clayton

Mike Poore

August 2014 


\section{DOCUMENT AVAILABILITY}

Reports produced after January 1, 1996, are generally available free via US Department of Energy (DOE) SciTech Connect.

Website http://www.osti.gov/scitech/

Reports produced before January 1, 1996, may be purchased by members of the public from the following source:

National Technical Information Service

5285 Port Royal Road

Springfield, VA 22161

Telephone 703-605-6000 (1-800-553-6847)

TDD 703-487-4639

Fax 703-605-6900

E-mail info@ntis.gov

Website http://www.ntis.gov/help/ordermethods.aspx

Reports are available to DOE employees, DOE contractors, Energy Technology Data Exchange representatives, and International Nuclear Information System representatives from the following source:

Office of Scientific and Technical Information

PO Box 62

Oak Ridge, TN 37831

Telephone 865-576-8401

Fax 865-576-5728

E-mail reports@osti.gov

Website http://www.osti.gov/contact.html

This report was prepared as an account of work sponsored by an agency of the United States Government. Neither the United States Government nor any agency thereof, nor any of their employees, makes any warranty, express or implied, or assumes any legal liability or responsibility for the accuracy, completeness, or usefulness of any information, apparatus, product, or process disclosed, or represents that its use would not infringe privately owned rights. Reference herein to any specific commercial product, process, or service by trade name, trademark, manufacturer, or otherwise, does not necessarily constitute or imply its endorsement, recommendation, or favoring by the United States Government or any agency thereof. The views and opinions of authors expressed herein do not necessarily state or reflect those of the United States Government or any agency thereof. 
Electrical and Electronics Systems Research Division

\title{
DOE-NE LETTER REPORT: KEY PARAMETERS FOR OPERATOR DIAGNOSIS OF BWR PLANT CONDITION DURING A SEVERE ACCIDENT
}

\author{
Dwight Clayton \\ Mike Poore
}

Date Published: August 2014

\section{Prepared by}

OAK RIDGE NATIONAL LABORATORY

\author{
Oak Ridge, Tennessee 37831-6283 \\ managed by \\ UT-BATTELLE, LLC \\ for the \\ US DEPARTMENT OF ENERGY \\ under contract DE-AC05-00OR22725
}





\section{CONTENTS}

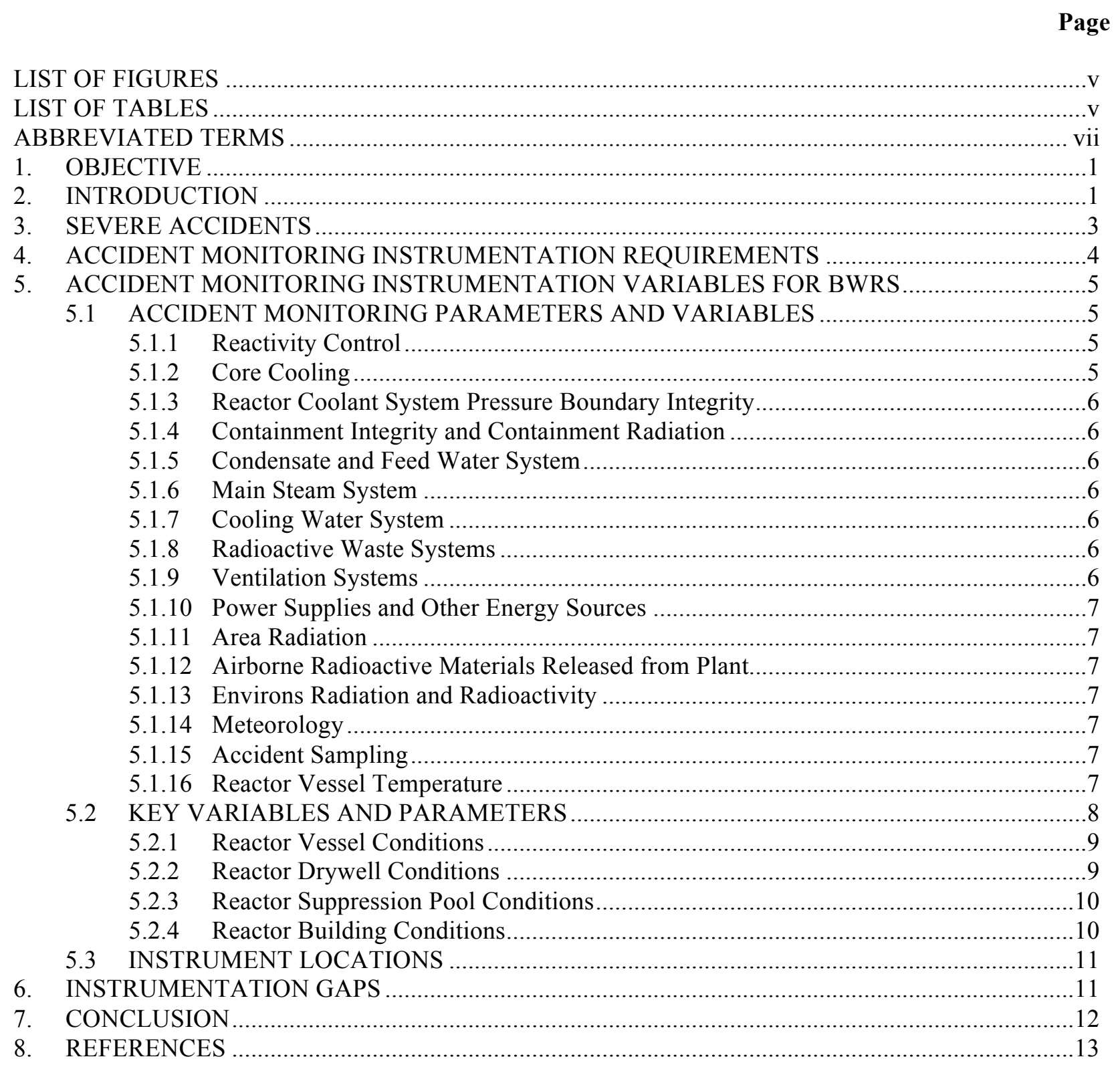





\section{LIST OF FIGURES}

Figure $\quad$ Page

Fig. 1. Actual vs calculated reactor pressure vessel water level—Fukushima Daiichi Unit 1...................2

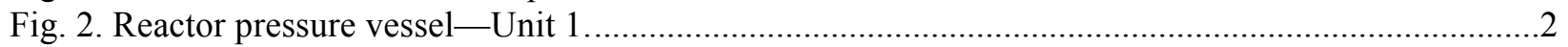

\section{LIST OF TABLES}

\section{Table}

Page

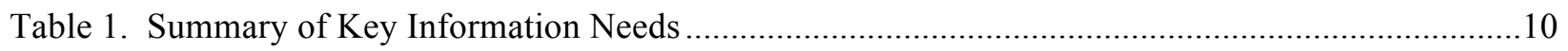

Table 2. Additional BWR-Mark I information needs ............................................................................ 12 



\section{ABBREVIATED TERMS}

$\begin{array}{ll}\text { ac } & \text { alternating current } \\ \text { BWR } & \text { boiling water reactor } \\ \text { CFR } & \text { Code of Federal Regulations } \\ \text { dc } & \text { direct current } \\ \text { EPRI } & \text { Electric Power Research Institute } \\ \text { IEEE } & \text { International Institute of Electrical and Electronics Engineers, Inc. } \\ \text { LOCA } & \text { loss-of-coolant accident } \\ \text { NRC } & \text { US Nuclear Regulatory Commission } \\ \text { ORNL } & \text { Oak Ridge National Laboratory } \\ \text { PWR } & \text { pressurized water reactor } \\ \text { RHR } & \text { residual heat removal } \\ \text { RPV } & \text { reactor pressure vessel } \\ \text { STP } & \text { standard temperature and pressure } \\ \text { TEPCO } & \text { Tokyo Electric Power Company } \\ \text { TMI } & \text { Three-Mile Island }\end{array}$





\section{OBJECTIVE}

The objective of this research is to examine the key information needed from nuclear power plant instrumentation to guide severe accident management and mitigation for boiling water reactor (BWR) designs (specifically, a BWR/4-Mark I), estimate environmental conditions that the instrumentation will experience during a severe accident, and identify potential gaps in existing instrumentation that may require further research and development. This report notes the key parameters that instrumentation needs to measure to help operators respond to severe accidents. A follow-up report will assess severe accident environmental conditions as estimated by severe accident simulation model analysis for a specific US BWR/4-Mark I plant for those instrumentation systems considered most important for accident management purposes.

\section{INTRODUCTION}

Oak Ridge National Laboratory (ORNL) completed a research activity recently [1] that examined the performance of BWR instrumentation and control systems during the days immediately following the Fukushima Daiichi accident, which began on March 11, 2011. That report, referred to in this document as "the ORNL Fukushima report," discussed the significant loss of monitoring and control instrumentation as a result of the accident, initially due to loss of power. Even after restoration of power, numerous instrumentation measurements were unavailable or were inaccurate, or differed in values and/or trends from other instruments measuring the same parameters. Instrument operating environment conditions certainly affected instrument performance. For example, Fig. 1 shows different reactor water level readings in redundant instruments A and B in the March 12 time frame for Fukushima Daiichi Unit 1 [2]. For several days after, there were no recorded reactor vessel water level readings from instrument A. Subsequent analysis results are quite different from either measured value. Fig. 2 shows reactor pressure readings for two redundant instruments, A and B, for Unit 1 [3]. Pressure readings are missing initially for instrument $\mathrm{A}$. Then, readings for the two instruments show opposite trends before readings converge between March 16 and 26. The readings diverge starting on March 26. The reason for the difference in readings for the two instruments was not provided. As they occur, such readings are given considerable attention by operators as they try to discern whether significant plant changes are taking place and as they try to gather complementary data to verify the readings.

The ORNL Fukushima report and this report on key parameters for operator diagnosis of plant conditions are part of continuing research efforts to identify and understand the performance of instrumentation used to monitor plant conditions, guide operator response to the events, and inform research to improve instrument performance in the challenging environment associated with severe accidents. Please refer to the ORNL Fukushima report for information on specific instrumentation issues and for references to many readily available detailed accounts of the accident. A parallel study on pressurized water reactor (PWR) instrumentation performance during the Three Mile Island (TMI) Unit 2 accident in 1979 was also conducted [4]. 


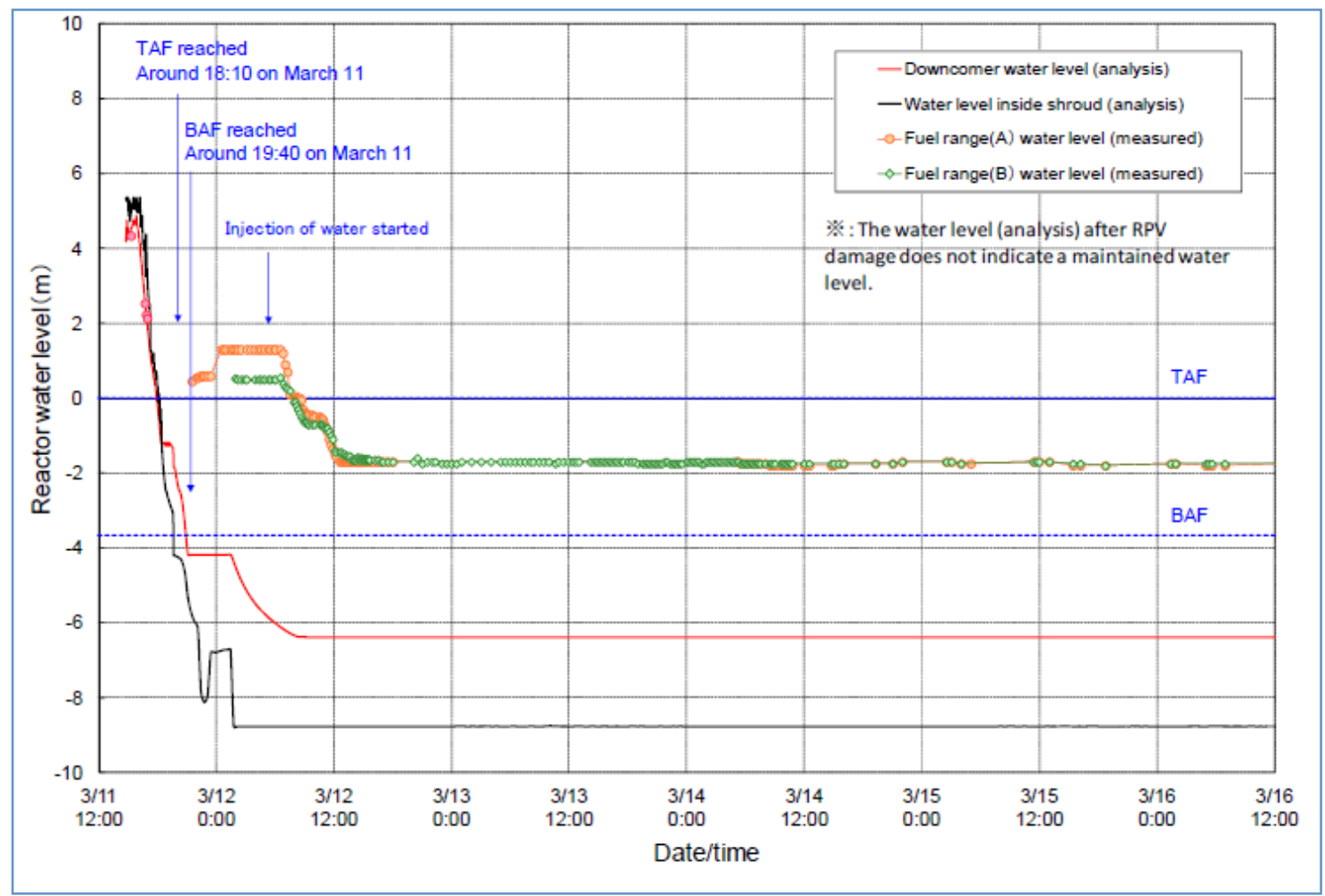

Fig. 1. Actual vs calculated reactor pressure vessel water level-Fukushima Daiichi Unit 1.

[(Tokyo Electric Power Company, Inc., Fukushima Nuclear Accident Analysis Report, June 20, 2012, p. 190, www.tepco.co.jp/en/press/corpcom/release/2012/1205638 1870.html.)]

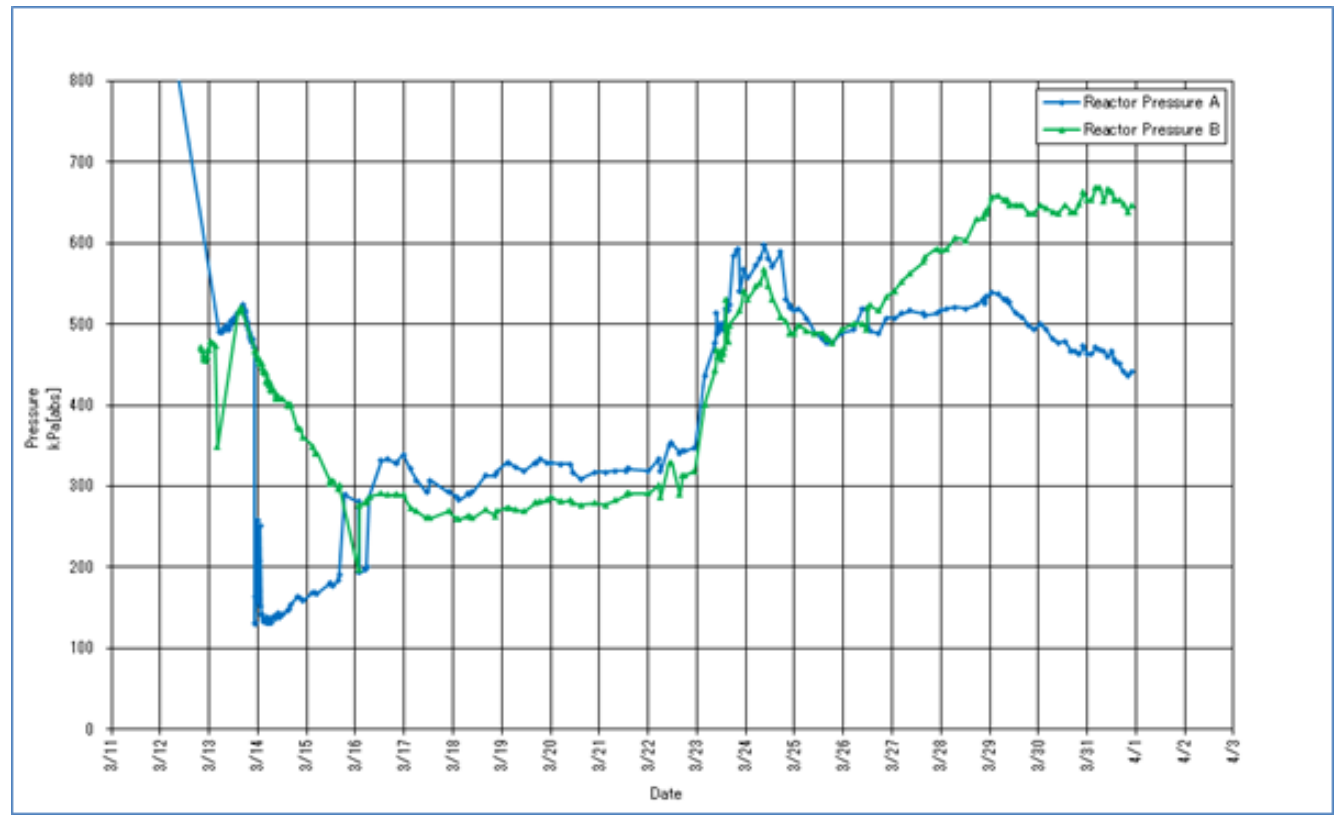

Fig. 2. Reactor pressure vessel-Unit 1.

[(Tokyo Electric Power Company, Inc., "The parameters related to the plants in Fukushima Daiichi Nuclear Power Station," Archives, 2011, www.tepco.co.jp/en/nu/fukushima-np/f1/pla/2011/index-e.html.)] 
Based on a review of the Fukushima Daiichi accident [2], instrumentation that had been monitoring plant parameters at Fukushima Daiichi survived the earthquake and the resulting loss of offsite power systems. Flooding from the tsunami damaged the onsite power systems for the six-unit site that were powering plant systems as designed following the loss of offsite power caused by the earthquake. This caused the loss of much instrumentation. At the time of the earthquake, Units 1-3 were operating and Units 4-6 were shutdown. Core damage occurred within hours at Unit 1 and within days at Units 2 and 3. Hydrogen generated from chemical reactions as the fuel failed at Units 1-3 was released from the reactor vessels into the reactor containments; at Units 1-4, hydrogen was released into the reactor buildings. (The Unit 4 reactor building was interconnected with Unit 3 through gas ventilation system piping.) Resulting deflagrations damaged reactor buildings and other structures, systems, and components of Units 1-4. An air-cooled diesel generator from Unit 6 survived the flooding and was configured to supply Units 5 and 6 with power following the tsunami to power critical systems at Units 5 and 6 . This prevented damage to fuel at those units.

The direct current (dc) power systems and electrical rooms for Units 1 and 2 were flooded and lost when the tsunami waves arrived. Unit 3 retained dc power system function until the batteries were exhausted. Measurement, monitoring, and communications systems were lost or degraded due to the loss of power. As power was restored by temporary batteries gathered by operators and later by more permanent sources, some instrumentation was able to be repowered. Remote measurement of many parameters was required due to problems repowering systems and control rooms.

As the accidents progressed, the performance of reactor instrumentation systems was affected not only by loss of power but also by the environmental conditions of the accident, including conditions following reactor pressure vessel (RPV) depressurization; containment pressure increases and pressure spikes from hydrogen deflagrations; and high temperatures, which affected RPV pressure and water level measurements. Core damage and RPV damage also released high levels of radioactivity, which can affect the performance of electronic systems, into containments. The impacts of these factors - high temperature, pressure pulses and spikes, high radiation doses, and water spray and flooding conditionsaffect instrumentation performance. Ultimately, this research will assess the environmental conditions of instrumentation during severe accidents and the consequences to instrumentation important for accident management purposes. As a result of this research, new technologies will be developed or existing technologies will be improved to ensure their usefulness in managing and mitigating severe accident conditions.

The goal of this work is to estimate the environmental conditions experienced by key BWR plant instrumentation during a severe accident. This report identifies a subset of plant accident monitoring instrumentation considered most important. The environmental conditions for this key instrumentation will be assessed in a follow-up task using a severe accident model application for the Peach Bottom Atomic Power Station BWR/4 under various severe accident scenarios [5]. The Peach Bottom study used integrated modeling of accident progression and offsite consequences that are considered to be state of the art. Its goal was a more realistic evaluation of accident progression, radioactive releases, and offsite consequences than had been done before. The model has pertinent features for the estimation of environmental conditions in various locations of the plant that will be applied based on the identification and location of key plant instrumentation for monitoring and guiding the operator response to a severe accident.

\section{SEVERE ACCIDENTS}

Nuclear reactors are designed to protect the public from harm associated with accidents by developing robust designs that accommodate normal foreseen operating conditions and less frequent but more serious challenges.

Designers provide systems to respond to these challenges. Some challenges are normal operating conditions that are anticipated to occur frequently over the design lifetime of the plant. Other challenges, 
termed anticipated operational occurrences, are expected to occur less frequently, maybe once or a few times over the life of the plant.

More serious challenges, design basis accidents, might not be expected to occur over the lifetime of the plant but could occur at a frequency high enough (e.g., less than $10^{-4}$ to $10^{-5}$ per year of reactor operation) and with consequences serious enough that they must be considered by the plant designers to ensure that accident consequences are within regulatory limits if they occur.

Another class of accidents - severe accidents, or beyond design basis accidents - could have serious consequences, but the expected frequency of occurrence is below a low threshold (e.g., less than $10^{-5}$ to $10^{-6}$ per year of reactor operation for typical current plants and less than $10^{-6}$ to $10^{-7}$ per year for more advanced designs). Severe accidents are considered to be so unlikely that plant designers do not have to design the plant to withstand them and ensure that accident consequences remain within regulatory limits.

The progression of the accident sequences at Fukushima Daiichi Units 1-3 occurred very much as predicted in prior severe accident research conducted in the United States [6] and internationally, given the complete station blackout that occurred when the tsunami generated by one of the most powerful earthquakes ever recorded rolled onshore.

Severe accident research noted the importance of instrumentation and control and monitoring systems and their dependence on dc electrical power systems when alternating-current (ac) electrical systems fail. Research in the early 1990s [7] addressed BWR instrumentation availability during severe accidents. Vulnerabilities of plant monitoring systems to various severe accidents were reviewed, and some responses were made. For example, at Fukushima Daiichi Units 2, 4, and 6, air-cooled diesel generators were added as part of the Tokyo Electric Power Company's (TEPCO's) accident management initiatives [8]. The generators provided redundancy and diversity to emergency power sources. However, because of flooded electrical panels, they could not be connected for use at Units 1-4.

\section{ACCIDENT MONITORING INSTRUMENTATION REQUIREMENTS}

Sound design practice and regulatory requirements address functional and design requirements for accident monitoring instrumentation. Regulatory guides and standards address performance criteria such as range, accuracy, response time, operating time, reliability and design criteria such a independence and separation, isolation, calibration, testability, maintenance, and repair. In the United States, for example, Criterion 13, "Instrumentation and Control," of Appendix A, "General Design Criteria for Nuclear Power Plants," to 10 CFR Part 50 [new reference 9] requires that "Instrumentation shall be provided to monitor variables and systems over their anticipated ranges for normal operation, for anticipated operational occurrences, and for accident conditions...." Criterion 19, "Control Room," requires reactor licensees to provide a control room "from which actions can be taken to operate the nuclear power unit safely under normal conditions and to maintain it in a safe condition under accident conditions...." Criterion 64, "Monitoring Radioactive Releases," requires reactor licensees "to provide a means for monitoring the reactor containment atmosphere, spaces containing components to recirculate LOCA fluids, effluent discharge paths, and the plant environs for radioactivity that may be released as a result of postulated accidents." The terms "accident conditions" and "postulated accidents" refer to design basis accidents in this context.

Subsection (2)(xix) of 10 CFR 50.34(f), “Additional TMI-Related Requirements," requires that licensees provide "instrumentation adequate for monitoring plant conditions following an accident that includes core damage."

The U. S. Nuclear Regulatory Commission (NRC) Regulatory Guide 1.97 addresses accident monitoring instrumentation. NRC Regulatory Guide 1.97, Revision 3, "Instrumentation for Light-WaterCooled Nuclear Power Plants to Assess Plant and Environs Conditions During and Following an Accident," dated May 1983 [new reference 10], provides a prescriptive approach to the design and qualification criteria for instrumentation and lists variables to be monitored. Revision 3 has been widely followed by the US nuclear fleet. Regulatory Guide 1.97, Revision 4, "Criteria for Accident Monitoring 
Instrumentation for Nuclear Power Plants," dated June 2006 [new reference 11], is intended for licensees of new nuclear power plants (that is, those plants licensed following the issuance of Revision 4).

Industry codes and standards, such as IEEE Std 497-2010 [9], "IEEE Standard Criteria for Accident Monitoring Instrumentation for Nuclear Power Generating Stations," and prior versions in 2002 and 1981 promulgated by the Institute of Electrical and Electronic Engineers (IEEE) establish criteria for accident monitoring instrumentation variable selection, performance, design, and qualification.

\section{ACCIDENT MONITORING INSTRUMENTATION VARIABLES FOR BWRS}

Accident monitoring instrumentation covers a spectrum of variables that support accident management needs and requirements. One class of variables is to inform manual actions to be taken by control room operators when no automatic controls are provided but are necessary for accomplishing safety functions for design basis events. Other classes show that safety functions such as reactivity control, core cooling, reactor coolant system integrity, and containment are being accomplished; indicate actual or potential breach of fission product release barriers; monitor the condition and performance of individual systems important to safety; and determine the magnitude of radioactive releases.

Severe accident computer models will be set up as part of a follow-up activity to estimate environmental conditions experienced by instrumentation that measures these variables. Thus key instrumentation deemed most important to guide operator monitoring, understanding, and response to a severe accident are identified so that conditions at those locations can be estimated.

\subsection{ACCIDENT MONITORING PARAMETERS AND VARIABLES}

NRC Regulatory Guide 1.97, Revision 3 [10], provides a specific list of instrument variables to monitor for PWRs and BWRs. Given that the BWR/4-Mark I plants are mature designs and were in use at the time Revision 3 was issued, the variables are highlighted here as typical of those needed for accident monitoring, recognizing that this guidance has been superseded, such as for new plants.

Variables to be monitored were broken into several categories and then into specific types of variables in each category. The various categories and variables within the categories are described in the following sections. Some variables are in multiple categories.

\subsubsection{Reactivity Control}

Variables associated with neutron flux (from $10^{-6}$ to $100 \%$ full power) are control rod position (full in or not full in) and the soluble boron concentration in a grab sample of reactor coolant.

\subsubsection{Core Cooling}

Variables associated with core cooling are reactor vessel water level (from the bottom of the core support plate to the lesser of the top of the vessel or the centerline of the steam line), reactor core temperature (a provision considered in the early 1980s), reactor core isolation cooling flow (from 0 to $110 \%$ design flow), high-pressure coolant injection flow (from 0 to $110 \%$ design flow), core spray system flow (from 0 to $110 \%$ design flow), low-pressure coolant injection system flow (from 0 to $110 \%$ design flow), standby liquid control system flow (from 0 to $110 \%$ design flow), residual heat removal (RHR) system flow (from 0 to $110 \%$ design flow), and RHR heat exchanger outlet temperature (from $\sim 5^{\circ} \mathrm{C}$ to $\left.180^{\circ} \mathrm{C}\right)$.

Variables specifically associated with fuel cladding are radioactivity concentration or radiation level in circulating primary coolant (from $50 \%$ to 100 times the technical specification limit) and gamma spectrum analysis of primary coolant (from $10 \mu \mathrm{Ci} / \mathrm{mL}$ to $10 \mathrm{Ci} / \mathrm{mL}$ or TID-14844 source term [10] in coolant volume). 


\subsubsection{Reactor Coolant System Pressure Boundary Integrity}

Variables associated with reactor coolant system pressure boundary integrity are reactor coolant system pressure (from 0 to $10.3 \mathrm{MPa}$ ), drywell pressure (from 0 to design pressure), drywell sump level (top to bottom), primary containment area radiation (from 0.01 to $1000 \mathrm{~Sv} / \mathrm{h}\left[1\right.$ to $\left.10^{5} \mathrm{R} / \mathrm{h}\right]$ ), and suppression pool water level (from bottom of emergency core coolant system suction line to $1.5 \mathrm{~m}$ above normal water level).

\subsubsection{Containment Integrity and Containment Radiation}

Variables associated with containment integrity are primary containment pressure (from about -35 $\mathrm{kPa}$ to 4 times design pressure [for steel] and from about -35 to $20 \mathrm{kPa}$ narrow range), suppression pool water level (from top of vent to top of weir well), suppression pool water temperature $\left(\sim 4^{\circ} \mathrm{C}-110^{\circ} \mathrm{C}\right.$ ), drywell atmosphere temperature $\left(\sim 4^{\circ} \mathrm{C}-230^{\circ} \mathrm{C}\right)$, drywell spray flow $(0-110 \%$ design flow $)$, primary containment isolation valve position (closed/not closed - excluding check valves), drywell hydrogen concentration (from 0 to $30 \mathrm{vol} \%$, from about $-35 \mathrm{kPa}$ to design pressure), containment effluent radioactivity from release points including standby gas treatment vent (from $10^{-6}$ to $10^{-2} \mu \mathrm{Ci} / \mathrm{cc}$ ), effluent radioactivity from buildings or areas where penetrations or hatches in direct contact with primary containment are located (from $10^{-6}$ to $10^{3} \mu \mathrm{Ci} / \mathrm{cc}$ ), primary containment area radiation-high range (from 0.01 to $10^{5} \mathrm{~Sv} / \mathrm{h}\left[1\right.$ to $\left.10^{7} \mathrm{R} / \mathrm{h}\right]$ ), and reactor building or secondary containment area radiation (from 0.001 to $100 \mathrm{~Sv} / \mathrm{h}\left[10^{-1}\right.$ to $\left.10^{4} \mathrm{R} / \mathrm{h}\right]$ for Mark I containments).

\subsubsection{Condensate and Feed Water System}

Variables associated with the condensate and feed water system are main feed water flow $(0-110 \%$ design flow) and condensate storage tank level (from top to bottom).

\subsubsection{Main Steam System}

Variables associated with the main steam system are main steam line isolation valve leakage control system pressure ( $\sim-380 \mathrm{~mm}$ water narrow range and $\sim 0-35 \mathrm{kPa}$ wide range) and primary system pressure relief valve and automatic depressurization system valve positions.

\subsubsection{Cooling Water System}

Variables associated with cooling water systems are cooling water temperature to engineered safety feature system components $\left(\sim 4^{\circ} \mathrm{C}-95^{\circ} \mathrm{C}\right)$ and cooling water flow to engineered safety feature system components $(0-110 \%$ design flow $)$.

\subsubsection{Radioactive Waste Systems}

A variable associated with the radioactive waste systems is the high-radioactivity liquid tank level (from top to bottom).

\subsubsection{Ventilation Systems}

A variable associated with ventilation systems is emergency ventilation system damper position (open-closed status). 


\subsubsection{Power Supplies and Other Energy Sources}

Variables (e.g., voltages, currents, pressures) associated with the status of standby power and other energy sources important to safety (e.g., electric, hydraulic, and pneumatic) are plant specific.

\subsubsection{Area Radiation}

A variable associated with area radiation monitoring is the radiation exposure rate inside buildings or areas where access is required to service equipment important to safety (from 0.001 to $100 \mathrm{~Sv} / \mathrm{h}\left[10^{-1}\right.$ to $\left.\left.10^{4} \mathrm{R} / \mathrm{h}\right]\right)$.

\subsubsection{Airborne Radioactive Materials Released from Plant}

Variables associated with monitoring airborne radioactive noble gases released from the plant are drywell purge and standby gas treatment purge (from $10^{-6}$ to $10^{5} \mu \mathrm{Ci} / \mathrm{cc}$ for 0 to $-110 \%$ vent design flow), secondary containment purge (from $10^{-6}$ to $10^{4} \mu \mathrm{Ci} / \mathrm{cc}$ for 0 to $-110 \%$ vent design flow), auxiliary buildings containing primary system gases such as decay tanks (from $10^{-6}$ to $10^{3} \mu \mathrm{Ci} / \mathrm{cc}$ for 0 to $110 \%$ vent design flow), and common plant vent (from $10^{-6}$ to $10^{3} \mu \mathrm{Ci} / \mathrm{cc}$ for 0 to $110 \%$ vent design flow).

Variables are associated with monitoring airborne radioactive particulates or halogens from all identified plant release points (from $10^{-6}$ to $10^{2} \mu \mathrm{Ci} / \mathrm{cc}$ for 0 to $110 \%$ vent design flow).

\subsubsection{Environs Radiation and Radioactivity}

Variables are associated with airborne radiohalogens and particulates (portable sampling-from $10^{-9}$ to $10^{-3} \mu \mathrm{Ci} / \mathrm{cc}$ ), plant and environs radiation (portable instrumentation-from $10^{-2}$ to $10^{5} \mathrm{mGy}$, photons; $10^{-2}$ to $10^{5} \mathrm{mGy}$, beta radiation and low-energy photons).

\subsubsection{Meteorology}

Variables associated with meteorology include wind direction $\left(0^{\circ}-360^{\circ}\right)$, wind speed $(0-22 \mathrm{~m} / \mathrm{s})$, and estimation of atmospheric stability based on the vertical temperature difference from the primary meteorological system.

\subsubsection{Accident Sampling}

Variables associated with primary coolant and sump sampling are gross activity (from 1 to $10 \mathrm{Ci} / \mathrm{cc}$ ), gamma spectrum (isotopic analysis), boron content (0-1000 ppm), chloride content (0-20 ppm), dissolved hydrogen or total gas $(0-2000 \mathrm{cc}(\mathrm{STP}) / \mathrm{kg})$, dissolved oxygen $(0-20 \mathrm{ppm})$, and $\mathrm{pH}(1-13)$.

Variables associated with containment air sampling are hydrogen content $(0-10 \mathrm{vol} \%, 0-30 \mathrm{vol} \%$ for inerted containments), oxygen content ( $0-30 \mathrm{vol} \%$ ), and gamma spectrum (isotopic analysis).

\subsubsection{Reactor Vessel Temperature}

Although not noted as an accident monitoring system variable in NRC Regulatory Guide 1.97, Revision 3 [10], a number of thermocouples (46 for one representative BWR vessel) measure reactor vessel temperature to monitor various vessel components to assess vessel stresses during heat-up and cooldown and have potential applicability and usefulness for certain accident conditions. 


\subsection{KEY VARIABLES AND PARAMETERS}

All of the variables noted in Section 5.1 are important from an accident monitoring perspective. However, some are especially critical to help the operators understand the conditions of the core and the reactor coolant system pressure boundary and the integrity of containment systems, and to act appropriately based on their severe accident management procedures and guidelines. Considerable research has been performed regarding information needs in a severe accident and has helped in the identification of key severe accident information.

An informative information-needs summary was given in EPRI TR-103412 [11]. That report presents a broad reference base that also includes EPRI TR-101869 [12]. This 1992 report provides candidate high-level actions taken and their effects following core damage used to support the development of severe accident management guidelines. EPRI TR-101869 was updated in EPRI TR-1025295 [13] in October 2012 to account for lessons learned from the Fukushima Daiichi accident and 20 years of research since the initial report. A pertinent observation from the 2012 report was that the original report has held up well and continues to be relevant and that the candidate high-level actions in the 1992 report "continue to represent appropriate responses to severe-accident conditions." Thus specific information needs to enable response to severe accidents remain much as they were as reported in prior research.

Evaluation of accident scenarios in early severe accident research, of which NUREG/CR-2182, Station Blackout at Browns Ferry Unit One-Accident Sequence Analysis[14] is an example, confirmed the vulnerability of instrumentation in severe accidents. This report assessed a station blackout scenario (loss of all ac electrical power-dc electrical power systems function until battery depletion). The scenario moves to a severe accident with core damage when the battery-powered dc electrical system loses power and the ability to monitor plant conditions and implement certain functions necessary to inject water into the core is lost. Alternative dc electrical power sources could provide drywell temperatures and reactor vessel temperature measurements for a longer period, perhaps giving indication that the core is uncovered. Mechanical level indicators available locally in the reactor building could also provide information about pending core uncovery. Essentially all accident monitoring capabilities would be lost as remaining battery power is depleted.

The information needed to manage severe accidents for BWRs with a Mark I containment was examined by research in the 1991 time period noted in NUREG/CR-5702, Accident Management Information Needs for a BWR with a MARK I Containment [15].

The ORNL Fukushima report [1] referenced numerous high level reviews of the Fukushima accident by Japanese and international entities that typically included lessons learned and implications from the entities' perspectives. Broadly speaking, the need for timely, accurate, and available instrumentation to convey information and measurements key to effective accident management was noted.

Staff from the Peach Bottom Atomic Power Station also provided support to identify key instrumentation needs through the sharing of emergency operating procedures, severe accident management plan procedures, and bases. These documents helped identify accident management actions and the information that informs them.

The loss of offsite, onsite, and dc power during the Fukushima accident was an obvious cause of the loss of instrumentation indications as well as the loss of safety system functions. The loss of power is a proximate cause of, or direct link to, instrument failure where typically restoration of power would restore function. Effects due to loss or restoration of power are not considered. The consequences of environmental conditions on the instrument performance, including the sensors, power and control cables, transducers, transmitters, reference and sensing lines, and indicators, etc., are important and will be addressed once the environmental conditions are estimated in a subsequent research task.

For the purposes of this report, portable instruments that could be used to measure releases within and external to the plant environs are not considered key instruments. Additionally, because of attention already placed on improved spent-fuel pool monitoring instrumentation (e.g., NRC Order EA-12-051 issued March 12, 2012, effective on issuance for licensees to modify licenses with regard to reliable spent fuel instrumentation [16]), spent fuel pool monitoring instrumentation is not addressed in this report. 
This research compares instrumentation capabilities with projected needs during severe accidents, given that core damage (i.e., fuel rod clad rupture and release of fission products into the reactor system) has already occurred, and focuses on objectives to prevent or delay core dispersal from the reactor vessel, maintain containment integrity, and mitigate fission product release.

For this study, key instrumentation is defined as instrumentation that operators can use to understand and respond to severe accidents, which are defined as accidents in which core damage has occurred. Key instrumentation reflects key as used here will assess key information needs, some of which may not be available:

- the status of the core in the vessel, including the ability to gauge whether effective cooling is taking place;

- the status of the reactor coolant pressure boundary, such as is it intact and likely to remain so; and

- the status of the reactor containment system and its ability to retain radionuclide releases and contain and cool ex-vessel core material.

The information needed to assess these three needs during a severe accident is a subset of the combined list of accident monitoring variables and parameters. Some variables could reasonably be in multiple categories.

\subsubsection{Reactor Vessel Conditions}

Several parameters or variables are necessary for operators to assess reactor core and reactor coolant pressure boundary conditions. For the purpose of this report, it is assumed that core damage has already occurred and that reactor protection systems have already actuated to take the reactor subcritical. From this initial condition, important information includes

- reactor core temperature, or fuel temperature, although this not measured directly in a BWR;

- reactor vessel water level, which is a key parameter to gauge whether the reactor fuel is covered with water and is thus being cooled;

- reactor vessel water injection flow rates;

- reactor vessel pressure, which is a key parameter to determine whether the reactor coolant pressure boundary is intact;

- reactor vessel pressure relief valve position;

- nuclear instrumentation to detect possible reactor not remaining subcritical; and

- reactor vessel temperature, which may be used to help an operator determine whether the reactor core has relocated to the bottom head of the reactor. This parameter is provided for specific operational situations and is not considered important to safety in current plants.

\subsubsection{Reactor Drywell Conditions}

Several parameters or variables are necessary for operators to assess the status, condition, and performance of the reactor drywell, one part of the BWR primary containment. Important parameters help gauge whether corium ejected from the reactor vessel would be submerged in water in the drywell, assess the integrity of primary containment, and determine conditions that could affect equipment or instrumentation. These parameters include

- drywell water level

- drywell pressure

- drywell hydrogen and oxygen concentrations

- drywell radiation

- drywell temperature

- drywell spray flow rate 
- containment isolation valve position indication

\subsubsection{Reactor Suppression Pool Conditions}

Several parameters or variables are necessary for operators to assess the status, condition, and performance of the suppression pool or wetwell, the second part of the design's primary containment. Important parameters gauge the conditions, integrity, and performance of the wetwell, including

- $\quad$ suppression pool water level

- $\quad$ suppression pool temperature

- suppression pool pressure

- suppression pool radiation

- $\quad$ suppression pool spray flow rate

- suppression pool hydrogen and oxygen concentration

\subsubsection{Reactor Building Conditions}

Several parameters or variables are necessary for operators to assess conditions in various areas of the reactor building where safety system equipment is located and where operators may have to go to take local measurements. Important parameters include

- area radiation

- $\quad$ area/room temperature

- equipment condition parameters

- pressure

- ventilation and exhaust radiation

- $\quad$ sump water levels or room water levels

Table 1 provides a summary of the key instrumentation needs for the reactor vessel, drywell, suppression pool, and reactor building areas.

Table 1. Summary of Key Severe Accident Information Needs

Reactor fuel temperature (no direct measurement)
Reactor vessel water level
Reactor vessel pressure
Reactor vessel water injection flow rates
Reactor vessel pressure relief valve position indication
Reactor vessel temperature
Drywell water level
Drywell pressure
Drywell hydrogen and oxygen concentration
Drywell radiation
Drywell temperature
Drywell spray flow rate
Containment isolation valve position indication (for reactor coolant
pressure boundary verification and containment integrity assurance)
Suppression pool water level
Suppression pool temperature
Suppression pool pressure
Suppression pool radiation
Suppression pool spray flow rate


Suppression pool hydrogen and oxygen concentration

Table 1. (continued)

Reactor building area radiation

Reactor building area temperature

Reactor building pressure

Ventilation and exhaust radiation

Sump or room water level

\subsection{INSTRUMENT LOCATIONS}

Once key instrumentation needs are determined, then instruments can be determined, including the locations of necessary subcomponents and support elements such as sensors, power and control cables, transducers, transmitters, reference and sensing lines, cabinets/racks, and indicators. Location information can then be used to estimate the various thermal hydraulic and radiation environmental conditions in those areas based on severe accident analysis tool predictions.

The MELCOR severe accident code [17] to be used for the upcoming analysis uses a nodalization scheme to estimate conditions in groups of areas. Usually a large number of nodes are required to accurately assess conditions of core and reactor vessel systems and structures. Fewer nodes are used for the containment volumes and reactor building volumes where "average" conditions in the volumes may be sufficient to support the thermal-hydraulic and radionuclide deposition analyses. Therefore, precision gained by determining exact locations of various instrumentation and support elements such as sensors, power and control cables, transducers, transmitters, reference and sensing lines, and indicators may be limited due to the fidelity of the models.

The progression and consequences of a severe accident, especially one with pressure spikes or hydrogen deflagration, also has considerable uncertainty that affects the degree of specificity helpful to estimate equipment environmental conditions. Ultimately, the severe analysis model will use some control volumes located in the reactor vessel. The locations of most control volumes in containment and reactor building will be selected for which thermal-hydraulic and radiation parameters will be estimated.

Descriptions of the model control volumes containing the key instrumentation will be provided in the later report that describes the severe accident model input and analysis results.

\section{INSTRUMENTATION GAPS}

The ORNL Fukushima report [1] contains references to a number of US and international entities who documented reviews and assessments of the Fukushima accident. The reviews typically included lessons learned that were potentially applicable to their own nuclear power generating stations and regulatory processes. Prior severe accident research also included forward-looking sections on potential improvements to severe accident instrumentation systems, such as the Chien and Hanson NUREG/CR5702 report [15], which noted that of the numerous accident monitoring instrumentation parameters, such as noted in U. S. Nuclear Regulatory Commission Regulatory Guide 1.97, Revision 3 [10], there were numerous information needs for which there were no direct information sources. These additional information needs, or gaps, are shown in Table 2 . These needs generally exist today.

The BWR Owners' Group Fukushima Response Committee also performed a tabletop evaluation [18] of strategies to mitigate severe accidents like the Fukushima Daiichi accident. The review incorporated the use of the US nuclear industry diverse and flexible coping (FLEX) capability [19] that could help mitigate a severe accident. Generic conclusions from this study noted that "Instrumentation and procedures to determine RPV core breach condition may also be needed" and that a need exists for improved procedure direction for shifting strategy between RPV injection and containment flooding. 
Implications for severe accident management included "Achieving a sufficient volume of water on the containment floor prior to vessel breach is needed to prevent containment failure" and noted that "Thermal conditions in the drywell head area could be challenging and should be reviewed."

\section{Table 2. Additional BWR-Mark I information needs}

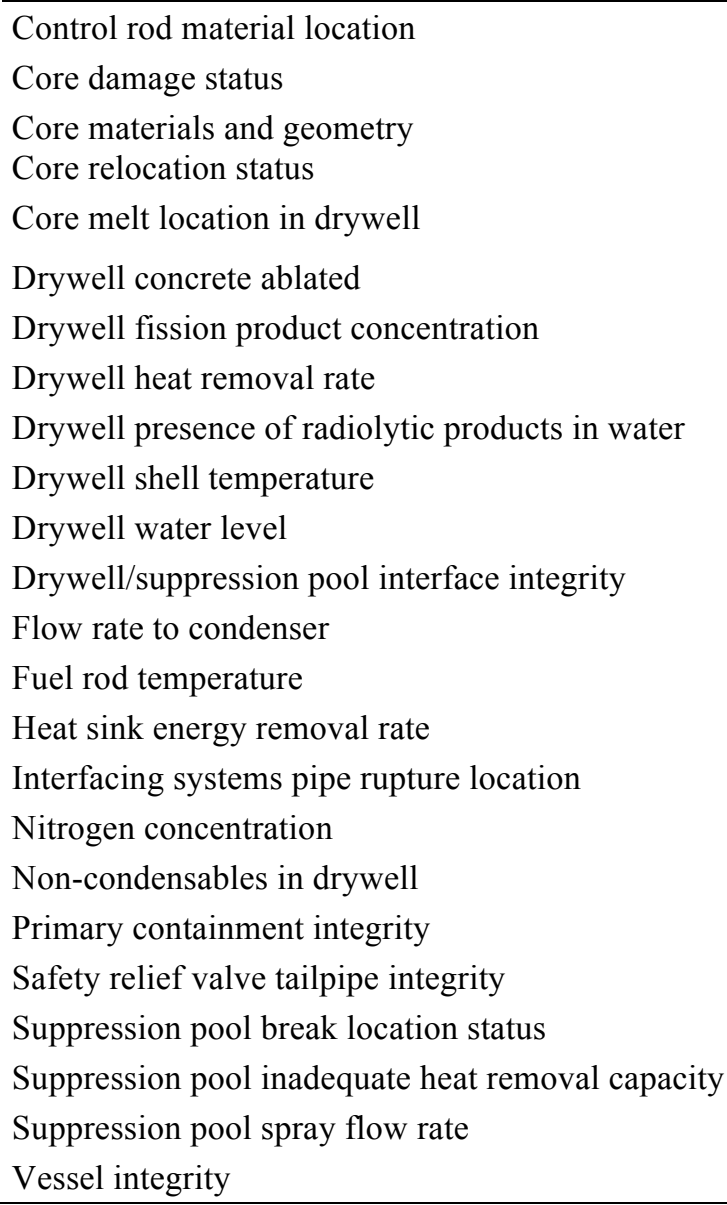

A pre-release draft of an International Atomic Energy Agency Nuclear Energy Series Report on accident monitoring systems was reviewed. This report, when released, will be a comprehensive resource for accident monitoring instrumentation system principles, selection of parameters for monitoring plant status, instrumentation design criteria, and areas where new methodologies or technologies may be needed.

\section{CONCLUSION}

This report is part of continuing research effort to identify and understand severe accident monitoring instrumentation performance and to inform research to improve instrumentation that must function in the challenging environment of a severe accident. It identifies key parameters needed from nuclear power plant instrumentation to guide severe accident management and mitigation for BWR/4-Mark I designs. The report also identifies potential gaps in existing instrumentation that would require further research and development. A subsequent report will provide analysis results of the application of a BWR severe accident modeling code to estimate the environmental conditions estimated for the instrumentation that provides these key parameters. 


\section{REFERENCES}

1. D. A. Clayton, W. P. Poore, III, Fukushima Daiichi-A Case Study for BWR Instrumentation and Control Systems Performance During a Severe Accident-Revision 1, ORNL/TM-2013/154, May 2014.

2. (Tokyo Electric Power Company, Inc., Fukushima Nuclear Accident Analysis Report, June 20, 2012, p. 190, www.tepco.co.jp/en/press/corp-com/release/2012/1205638 1870.html.)

3. (Tokyo Electric Power Company, Inc., "The parameters related to the plants in Fukushima Daiichi Nuclear Power Station," Archives, 2011, www.tepco.co.jp/en/nu/fukushima-np/f1/pla/2011/indexe.html.)

4. J. L. Rempe, D. K. Knudson, TMI-2 - A Case Study for PWR Instrumentation Performance During a Severe Accident, INL/EXT-13-28043 Revision 1, May 2014.

5. Sandia National Laboratories, State-of-the-Art Reactor Consequence Analyses Project, Volume 1: Peach Bottom Integrated Analysis, NUREG/CR-7110, Vol. 1, January 2012.

6. For an informative overview see S. R. Greene, The Canary, the Ostrich, and the Black Swan: An Historical Perspective on our Understanding of BWR Severe Accidents and their Mitigation, American Nuclear Society International Meeting on Severe Accident Assessment and Management: Lessons Learned from Fukushima Dai-ichi, November 12, 2012, San Diego, Calif.

7. W. C. Arcieri and D. J. Hanson, Instrumentation Availability During Severe Accidents for a Boiling Water Reactor with the Mark I Containment, NUREG/CR-5444, Idaho National Engineering Laboratory, Idaho Falls, Idaho, February 1992.

8. Investigation Committee on the Accident at the Fukushima Nuclear Power Stations of Tokyo Electric Power Company, Interim Report, December 26, 2011, www.cas.go.jp/jp/seisaku/icanps/eng/interimreport.html.

9. New

10. New

11. New

12. IEEE publications may be purchased from the IEEE Service Center, which is located at 445 Hoes Lane, Piscataway, NJ, 08855 [http://www.ieee.org, phone (800) 678-4333].

13. In 1962, the US Atomic Energy Commission published TID-14844, Calculation of Distance Factors for Power and Test Reactors, which specified a source term for a substantial meltdown of a reactor core.

14. Electric Power Research Institute, Assessment of Existing Plant Instrumentation for Severe Accident Management, EPRI TR-103412, December 1993. (Download at www.epri.com)

15. Electric Power Research Institute, Severe Accident Management Guidance Technical Basis Report, Vols. 1 and 2, EPRI TR-101869, December 1992. (Download at www.epri.com)

16. Electric Power Research Institute, Severe Accident Management Guidance Technical Basis Report, EPRI TR-1025295, October 2012. (Download at www.epri.com)

17. D. H. Cook, et. al., Station Blackout at Browns Ferry Unit One-Accident Sequence Analysis, NUREG/CR-2182, ORNL/NUREG/TM-455/V1, November 1981.

18. D. N. Chien and D. J. Hanson, Accident Management Information Needs for a BWR with a MARK I Containment, NUREG/CR-5702, Idaho National Engineering Laboratory, May 1991. 
19. NRC Order Ea-12-051, Order Modifying Licenses with Regard to Reliable Spent Fuel Pool Instrumentation (Effective Immediately), issued March 12, 2012 (ADAMS Accession No. ML12056A044.)

20. See http://melcor.sandia.gov

21. BWR Owners' Group, BWROG Fukushima Response Committee: Plant Evaluation of Severe Accident Mitigation Strategies, BWROG-TP-13-001, Revision 1, January 2013

22. Nuclear Energy Institute, FLEX: The Industry Strategy to Enhance Safety, safetyfirst.nei.org/industryactions/flex-the-industry-strategy-to-enhance-safety/. 